ORIGINAL PROF-2251

\title{
EPIDEMEOLOGY OF HOMICIDAL DEATHS;
}

IN SARGODHA, PAKISTAN

Dr. Bashir Ahmed Siddiqui, Dr. Ahmed Saeed, Dr. Uzma Masud, Dr. Zafar Latif Awan, Dr. A.R. Khawaja

ABSTRACT... Objectives: 1). To observe \& analyze the different aspects of homicidal deaths in Sargodha in terms of age, sex, weapon involved and seasonal variation. 2). To compare it with other studies conducted in Pakistan \& all over the world. Study Design: Noninterventional descriptive study. Place \& duration of study: The study was done on autopsies conducted at mortuary, District Headquarter Teaching Hospital Sargodha from January 2012 to December 2012 (one year). Material \& Methods: 82 cases of homicidal deaths which were brought by police for autopsy examination at DHQ Teaching Hospital Sargodha from Jan. 2012 to Dec. 2012. These cases include both sexes of all age groups. Manner of death was decided on the basis of police inquest \& autopsy report. The relevant data was collected on prescribed performa and statistically analyzed. Results: On analysis of recorded data, the homicidal rate in Sargodha, Pakistan is $7.59 / 100,000$ populations per year. Homicide manner of death was observed $51.25 \%$ of total autopsies. $39 \%$ of the victims were in the third decade of life. Males predominated females by a ratio of 2.28:01 Firearm was used in most of homicidal deaths i.e. $67 \%$. A rise in homicidal cases was observed in the months of summer i.e. June to September 2012 and a fall was observed in the months of winter i.e. November, December, January and February, 2012. Conclusions: Homicide rate is high as compared to other manners of death in Sargodha. Firearm is the major weapon used for committing homicide.

Key words: Homicide, Firearms, Autopsy, Seasonal variation, Manner of death

Article Citation

Siddiqui BA, Saeed A, Masud U, Awan ZL, Khawaja AR. Epidemiology of homicidal deaths in Sargodha, Pakistan. Professional Med J 2013;20(5): 793-797.

\section{INTRODUCTION}

According to Nolo's Plain-English Law Dictionary, Homicide is "the killing of one human being by the act or omission of another". Homicide may be criminal or lawful. In a number of situation killing is legal and not criminal. It may be in self defense or may be due to war. It may also be result of a sentence or verdict of a court. "Criminal homicide occurs when a person purposely, knowingly, recklessly, or with extreme negligence causes the death of another" ${ }^{11}$.

Assailant, victim and circumstance all are important when we come across an assault. When we look into assailant or victim, characteristics are important. Location of occurrence, age, gender, occupation, social background, race or ethnic origin, gun or instrument used, motive or psychological profile, circumstance and relation with the victim is important $^{2,3}$.

Homicide is a major crime in all codes of law. It is a crime that is reported and analyzed reliably and regarded serious, socially as well as legally. If interpersonal conflicts resulting in this crime are to be studied we need to consider circumstances, relationships and stages of life of the assailant and the victim ${ }^{4}$.

The question whether mass media violence triggers additional aggression in society has been extensively studied in the developed world. TV not only teaches various behaviors to the viewers but also modifies their psyche. Homicides may also be triggered by violence that is shown on TV ${ }^{5}$.

217 studies about TV violence were analyzed through meta-analysis and showed watching violence on TV significantly aroused aggression and antisocial behavior more among viewers of youngest age ${ }^{6}$.

There is a great variation in the frequency of homicide in the world ranging from 0.45 (Japan) to 59.5 (Jamaica) / 100,000 population/ year ${ }^{7}$. In Pakistan, it 
is $6.81 / 100,000$ population / year? .

Homicide is reported more commoner in the younger age group ${ }^{8,9,20,21,22}$. Males are the predominant victims amongst the cases of homicide ${ }^{8,10,20,21,22}$. The weapon used to commit homicide varies in different parts of the world but is mostly a firearm ${ }^{8,11,20,21,23}$. Homicidal activity is observed more common in the months of summer ${ }^{8,12}$.

Sargodha is a city of rural / agricultural background. It is undergoing transformation from small to big city. The study was carried out to know the frequency of homicidal deaths in Sargodha city, involvement of gender \& age groups, the weapons being used to inflict such deaths and seasonal trends. Knowing the magnitude and dimensions of a problem is the first step to solve or eradicate that problem.

\section{MATERIALS AND METHODS}

The cases were labeled as homicide on the basis of police inquest and autopsy findings. These homicidal cases were selected from all the autopsies conducted at the DHQ Teaching Hospital Sargodha from 01-012012 to 31-12-2012. These cases were grouped on the basis of age, sex, causative weapon and the season in which the incident took place. The data was recorded on a performa and the results were analyzed.

\section{RESULTS}

During the period under study, out of 160 autopsies conducted at DHQ Hospital, Sargodha 82 deaths were of homicide nature, thus being $51.25 \%$ of all deaths reported for autopsy (Table-I).

Sargodha city is having a population of 1.08 million during the study period; the rate of homicide comes out to be 7.59 per 100,000 populations per year.

Majority of the victims were between the age of 20-39 years, out of which 32 cases were in the third decade of life and 22 in the fourth decade. Agewide distribution of the homicidal cases is given in Fig. 1 .

Males outnumbered females by a ratio of 2.28:1. Sex distribution is shown in Fig.2

\begin{tabular}{|c|c|c|}
\hline Manner of death & No. of cases & $\begin{array}{c}\text { \%age of total } \\
\text { autopsies }\end{array}$ \\
\hline Homicidal & 82 & $51.25 \%$ \\
\hline Suicidal & 02 & $01.25 \%$ \\
\hline Accidental & 54 & $33.75 \%$ \\
\hline Natural & 22 & $13.75 \%$ \\
\hline Total cases & 160 & $100.00 \%$ \\
\hline \multicolumn{2}{|c|}{ Table-I. Distribution of cases according to } \\
manners of death
\end{tabular}

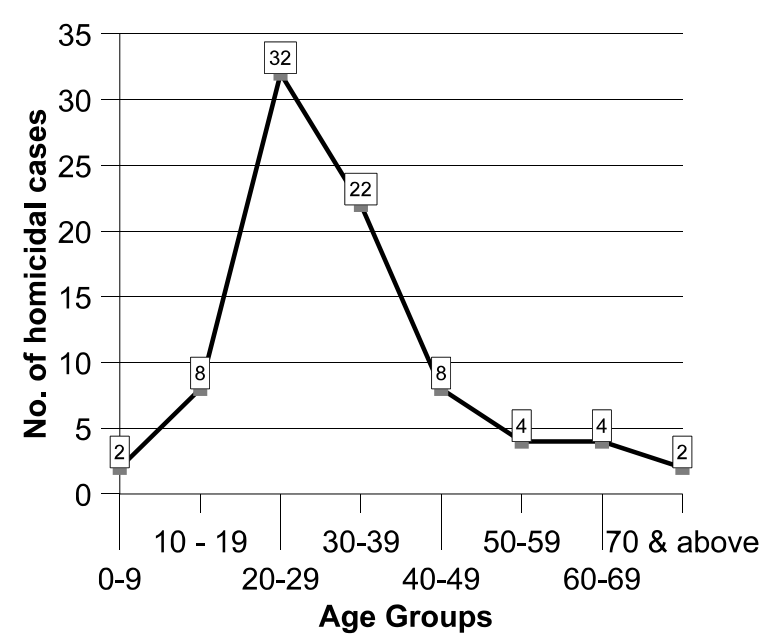

Fig-1. Age wise distribution of homicidal deaths

The predominating weapon for committing homicide is firearm, which is used in 55 cases, followed by sharp edged \& blunt weapons equally (10 cases of each) shown in table-Il.

The greatest numbers of homicide are committed during the hot summer (August and September) whereas the lowest number is in February as shown in fig.3 


\begin{tabular}{|c|c|c|}
\hline $\begin{array}{c}\text { Weapon / Method used for } \\
\text { homicidal }\end{array}$ & No. of cases & \%age \\
\hline Firearm & 55 & $67.00 \%$ \\
\hline Blunt & 10 & $12.20 \%$ \\
\hline Sharp / pointed & 10 & $12.20 \%$ \\
\hline Asphyxia & 05 & $06.10 \%$ \\
\hline Poisoning & 02 & $02.50 \%$ \\
\hline Total & 82 & $100.00 \%$ \\
\hline
\end{tabular}

Table-II. Distribution of cases on the basis of

Weapons/Methods causing Deaths

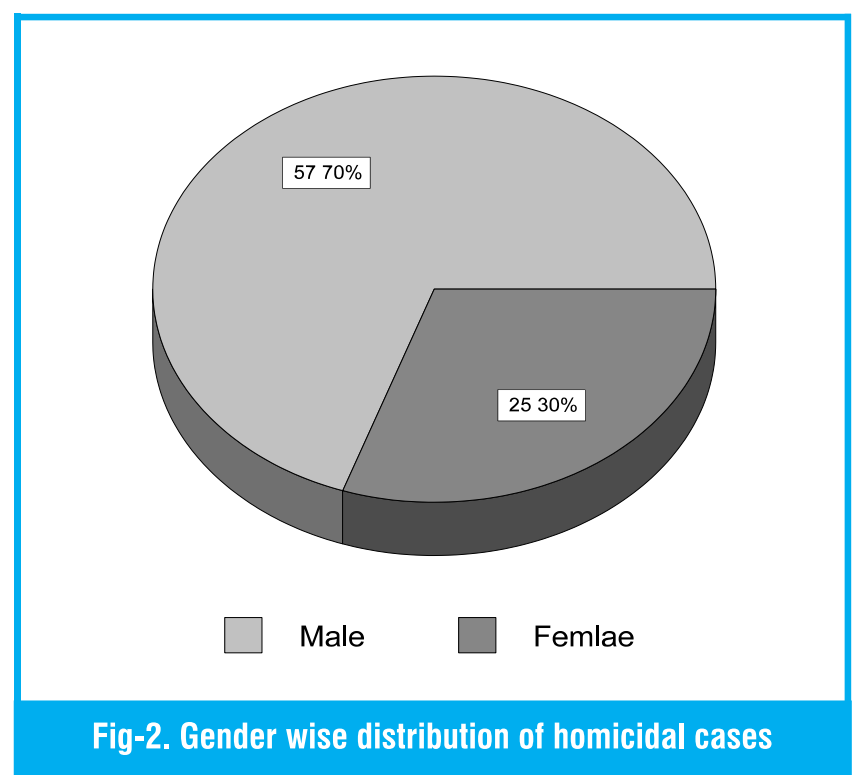

\section{DISCUSSION}

The study was conducted from January 2012 to December 2012 at DHQ Teaching Hospital Sargodha. Homicidal deaths were $51.25 \%$ of the total autopsies. This percentage is lower than in other cities of Pakistan like Lahore ${ }^{8}$ (79.66\%), Peshawar ${ }^{13}$, (77.7\%), Faisalabad $^{14}(79.66 \%)$ and D.I. Khan $^{15}(76 \%)$ Mirpur $^{20}$, AJK (90.91\%), Kasur ${ }^{21}$ (82.26\%).

During study period, total population of Sargodha city was 1.08 million. The rate of homicidal deaths being 7.59 / 100,000 population per year which is higher than the overall homicidal death rate in Pakistan $(6.81)^{7}$. This may be due to agriculture background of Sargodha city and poor law and order situation.

The death rate in our study $(7.59$ / 100,000 population per year) is much higher than other countries like Bangladesh (2.5), India (2.77), USA (5.22), UK (1.57), Germany(0.8), China (1.21), Saudi Arabia (0.85), Turkey (2.94) ${ }^{7}$ and district Muzaffarabad AJK (2.748). Whereas it is lower than Indonesia (9.29), Russian Federation (14.18), South Africa (36.54), Sudan $(36.54)^{7}$. However in some other metropolitan cities of the world, death rates from 31 to 124 / 100000 population has been reported $d^{9,17,18}$.

Male population predominated the female population by 2.28:1 ratio regarding homicidal death in our study which is consistent with other studies in Pakistan ${ }^{8-14-}$ $19,20,21,22$. This may be due to the nature of male group and male dominant society where males settle most of the disputes and conflicts.

In our study the homicide is common among younger age group ranging from $3^{\text {rd }}$ decade $(39.00 \%)$ to 4 th decade (26.80\%) amounting to $65.80 \%$. Other studies from Pakistan also reveal that the most common victims of homicide are young \& middle aged adults. So our results are quite similar with other studies in Pakistan ${ }^{8,14,19,20,21,22 .}$

Peak incidence of homicide is observed in our study during the summer season (i.e. June 2012 to September 2012).The same is reported in other studies conducted in Pakistan ${ }^{8,12,14}$. It is due to the fact that the contact time among the people increases due to longer day times, which in turn increase the risk of more disputes and adverse effects of hot season on the temperament.

The firearm weapons is the leading cause of homicidal deaths in our study i.e. $67 \%$ which is consistent with other studies in Pakistan ${ }^{8-13-14-15-19,20,21,23}$ and other 
countries with a high level of firearm possession ${ }^{11-17}$. The reason of this may be due to the legal and illegal possession of latest sophisticated firearm weapons through which committing homicides is easier as compared to other means.

Keeping in view the above results of the study, good governance \& de-weaponisation may be required to minimize the rate of homicidal deaths. Moreover, it is shocking situation in Pakistan as well as in our study area that homicide rate is so high in this society. A society that is said to have faith in the Quranic injunctions, which clearly declare that the killing of one person is equal to the killing of the whole mankind. So it may be said that practicing of the Islamic principles would also be helpful to minimize the murder incidence, as Islam not only condemns the homicides strongly but also recommends the severe punishment for this act (tit for tat).

Copyright(C) 22 May, 2013.

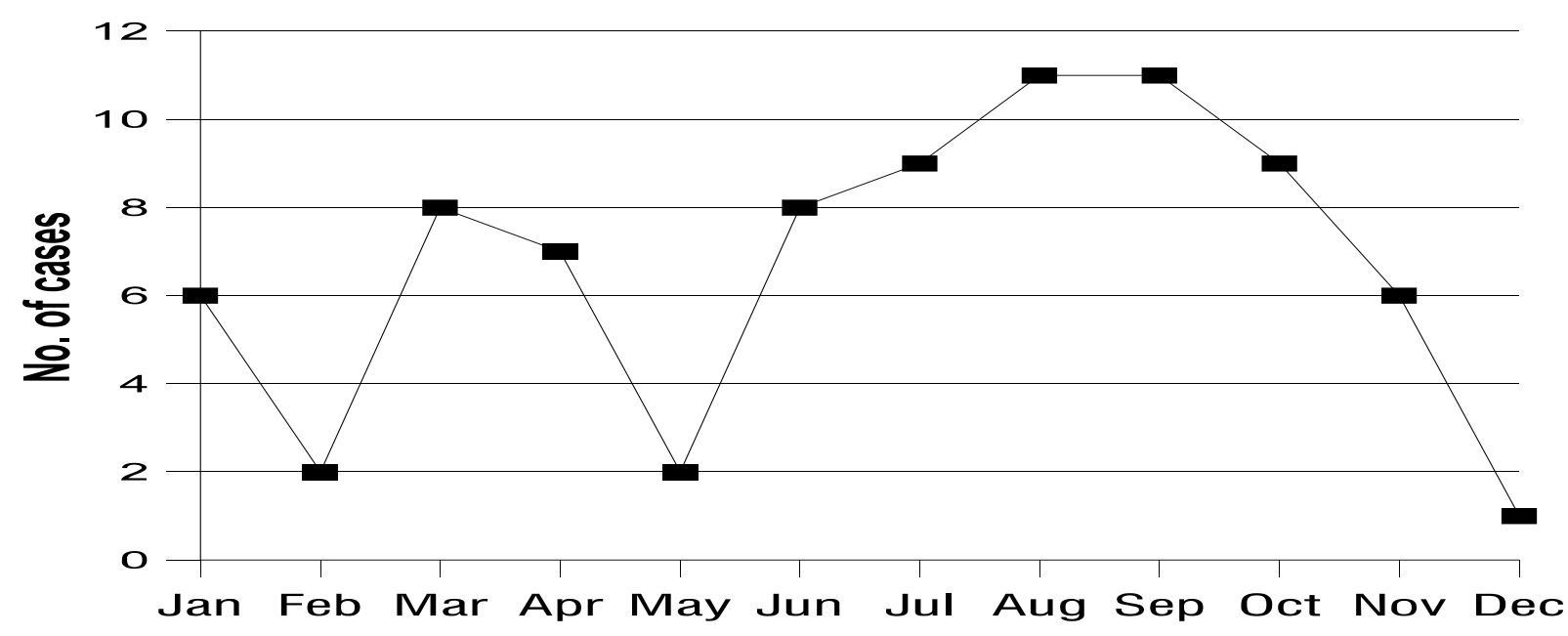

\section{Fig-3. Month wise distribution of homicidal cases}

\section{REFERENCES}

1. Hill G. , K. Hill K., (2009). Homicide. In Irving S, Nolo's Plain-English Law Dictionary (Hill G. , K. Hill K., 2009).

2. Berkowitz, L. (1993). Aggression: Its causes, consequences, and control. New York: McGraw-Hill. (Berkowitz, 1993).

3. Bandura, A. (1986). Social Foundations of Thought and Action: A Social Cognitive Theory. Englewood Cliffs, N.J.: Prentice-Hall. (Bandura, 1986).

4. Daly M. and Wilson M. (1997). Crime and Conflict: Homicide in Evolutionary Psychological Perspective. Crime \& Justice, 22, 51-100. (Daly and Wilson, 1997).

5. Phillips, D. P. (1983)., The Impact of Mass Media Violence on U.S. Homicides. American Sociological
Review., Vol. 48, No. 4 (Aug., 1983), pp. 560-568 (Phillips, 1983).

6. Paik H. and Comstock G., (1994)., "The Effects of Television Violence on Antisocial Behavior: A MetaAnalysis," Communication Research 21:4: 516-546. (Paik and Comstock, 1994).

7. Current World wide Murder/Homicide Rate at www.chartsbin.com, 05-10-2012.

8. Aziz K, Rana P, Malik SA. Homicide in Lahore. Pakistan Postgraduate Medical Journal 1999; 10(1):10-13.

9. Concha-Eastman A, Espitia VE, Espinosa R, Guerrero $R$. Epidemiology of homicides in Cali, Columbia,1993-1998:six years of a populationbased model. Rev Panam Salud Publica 2002;12(4):230-9. 
10. Batten PJ, Hicks LJ, Penn DW. A 28-year (1963-90) study of homicide in Marion County, Oregon. Am J Forensic Med Pathol 1991; 12(3):227-34.

11. Chu LD, Sorenson SB. Trends in California homicide, 1970 to 1993. West J Med. 1996; 165(6):297-8.

12. Memon MU, Khalil ZH, Aziz K, Kaheri GQ,Khalil IR. Audit of cases autopsied in the mortuary of Khyber Medical College Peshawar during the year 1999. Annals 2001; 7(3):190-3.

13. Zahid Hussain, Mian Mujahid Shah, Hakeem Afridi, Homicidal deaths by firearms in Peshawar: An Autopsy study, J Ayub Medical College, Abbotabad $200618(1)$.

14. M. Zahid Bashir, Ahmad Saeed, Dilawar Khan, Pattern of homicidal deaths in Faisalabad, JAyub Medical College, Abbotabad 2004 16(2).

15. M. Humaun, Dilawar Khan, Fasee-UZ-Zaman, Analysis of homicidal deaths in Districts D.I.Khan, An Autopsy study, JAyub Medical College, Abbotabad 200921(1).

16. Whitman S, Benbow, Good G. The epidemiology of homicide in Chicago. J Natl Med Assoc 1996; 88(12):781-7.

\section{AUTHOR(S):}

1. DR. BASHIR AHMAD SIDDIQUI

Assistant Professor, Forensic Medicine, Sargodha Medical College, Sargodha.

2. DR. AHMED SAEED

Professor of Forensic Medicine

Gujranwala Medical College, Gujranwala

3. DR. UZMA MASUD

Demonstrator Forensic Medicine Department

Punjab Medical College, Faisalabad.

4. Dr. Zafar Latif Awan

Assistant Professor

Department of Community Medicine

Sargodha Medical College, Sargodha
17. Duflou JA, Lamont DL, Knobel GJ. Homicide in Cape Town, South Africa. Am J Forensic Med Pathol 1988; 9(4):290-4.

18. Chughtai BR, Uraizy SMH, Rashid MA, Chaudry TH, Ahmed B, Qureshi GAA. The Professional 2002; 9(4):316-9.

19. Blumstein A. Youth, guns, and violent crime. Future Child 2002; 12 (2): 38-53.

20. Agha S A, Khan J, Rehman S, Zarif P, A study of Homicidal deaths in Mirpur District of Kashmir, Pakistan Gomel Journal of Medical sciences July to December 2012, V.P 10, No. 02.

21. Shoukat Ali, Akmal Shaheen, Romela Naz, Muhammad Iqbal Mughal, Parvaiz Zarif. A breakup of autopsies conducted at District Head Quarter Hospital, Kasur. J Medical Forum Monthly September, 2012 Vol.23, No.09.

22. Khan NA, Hashme RI, Sheikh NA, Akhtar W. Pattern of homicide in Muzaffarabad (AJK), J Medical Forum Monthly September, 2012 Vol.23, No.09. Page 21-23 ISBN 1029-385x.

23. Shoukat Ali, Akmal Shaheen, Parvaiz Zarif, Muhammad lqbal Mughal. Firearm injuries pattern in cases autopsied at DHQ Hospital, Kasur. J Medical Forum Monthly January, 2012 Vol.23, No.01.

5. Dr. Abdul Rehman Khawaja Monitoring Evaluation Officer MIS Cell, Directorate General Health Services, 24-Cooper Road, Lahore.

Address for Correspondence:

Dr. Bashir Ahmad Siddiqui,

Assistant Professor, Forensic Medicine,

Sargodha Medical College, Sargodha.

drbashir.167@gmail.com

\section{PREVIOUS RELATED STUDIES}

Babur Rashid Chughtai, Mian abdur Rashid, Tajammal Hussain chaudhery, Bashir Ahmed, G A Asghar Qureshi. Incidence of Homicidal Deaths (Original) Prof Med Jour 9(4) 316-319 Oct, Nov, Dec, 2002. 